\title{
Risk Mitigation in Managing a Mega Project - a Case Study of Gomal Zam Dam Construction
}

\author{
George Wang \\ Department of Construction, East Carolina University \\ Greenville, North Carolina, 27858-4353, USA \\ E-mail: wangg@ecu.edu \\ Wei Hu \\ Department of Construction, East Carolina University \\ Greenville, North Carolina, 27858-4353, USA \\ E-mail: wangg@ecu.edu,huw13@students.ecu.edu \\ Colin Duffield \\ Department of Infrastructure Engineering, University of Melbourne \\ Parkville, Victoria, 3010, Australia \\ E-mail: colinfd@unimelb.edu.au
}

Received 21 January 2014

Accepted 20 March 2014

\begin{abstract}
Global contractors operate in an environment that has a variety of alternatives and uncertain circumstances that requires constant circumvention and adjustment. It is not uncommon that a contractor conducting an international project does not comprehensively evaluate the local environments and identify and assess potential risk factors thoroughly and respond and forewarn its teams promptly. Gomal Zam Dam Multi-Purpose project includes the highest roller compacted concrete gravity dam in Pakistan and a hydropower generation station. The construction started in 2007 and inaugurated in 2013. During the construction, the construction management level of the contractor faced many challenges and risks not previously identified. These risks impacted the construction in various aspects including schedule, cost, and finance control. This paper provides the background information of the project, the specifics of the project and challenges encountered. It also presents the countermeasures and management techniques used under the multitude of uncertainties in this mega infrastructure project, the management lessons learned during the six years construction. In view of the growing global construction and construction management projects worldwide, the practices in this infrastructure project will provide referential experience to international companies and construction managers pursuing projects in Pakistan.
\end{abstract}

Keywords: Construction, Risk, Pakistan, Infrastructure, Dam.

\section{Introduction}

The construction industry is a major industry generating approximately ten percent of global gross domestic product (GDP) and it accounts for an investment of approximately US\$6 trillion in 2012 (IHS, 2013). On the other hand, rapid globalization has impacted the construction industry when project managers and engineers seek work or pursue projects in international markets. Ten to twenty years ago, international construction projects were conducted in developing countries by companies from developed countries (Raftery et al., 1998). However, in more recent years, there have been dramatic changes in the international construction market. Construction companies, foreign engineers and project managers from developing 
countries are entering both developed and developing countries in significant numbers.

For an international construction company, conducting a mega construction project in an underdeveloped country they will generally face many unfavorable uncertainties and risks. Unfortunately, the "total risk management" defined by Construction Industry Institute (CII, 2003; Walewski et al., 2006) is not practiced by many global contractors. The experience and lessons learned are summarized based on the Gomal Zam Dam multiple construction project, in which the second author was involved in Pakistan during the construction.

\section{Project Background Information}

Pakistan is the sixth most populous country in the world with an estimated population of over 183 million. Its size is approximately 796,120 square kilometers (307,400 square miles) which is slightly larger than New Mexico. The capital city is Islamabad and the largest city is Karachi City. English is the official language, while Urdu is the predominate spoken language.

The Gomal Zam Dam project is located in the south of Waziristan Agency in the Federally Administered Tribal areas which approximately $35 \mathrm{~km}$ (22 miles) away from the Town of Wana and $50 \mathrm{~km}$ (31 miles) away from the Town of Tank. The nearest city to project site is Dera Ismail Khan (D. I. Khan) which is about $150 \mathrm{~km}$ (94 miles) away. The dam impounds the Gomal River, a tributary of Idus River, at Khajuri Kach. The purpose of the dam is for irrigation, flood control and hydro electrical power generation. Figure 1 indicates the approximate geographical location of the dam.

The dam project was first envisaged and surveyed in 1898 by the Royal Corps of Engineers. The construction of the dam was approved by Pakistan government in August 1963 and preparatory work was commenced. However, the project was stopped due to the outbreak of the 1965 Indo-Pak War and by subsequent budgetary constraints. In 2001, the construction of the dam was ordered to start and the groundbreaking ceremony was held on August 14, 2001. Early in 2002, a Chinese joint venture (JV), China National Water Resources \& Hydropower Engineering Corporation and Harbin Power Engineering Company (CWHEC-HPE) was hired by Pakistan Water and

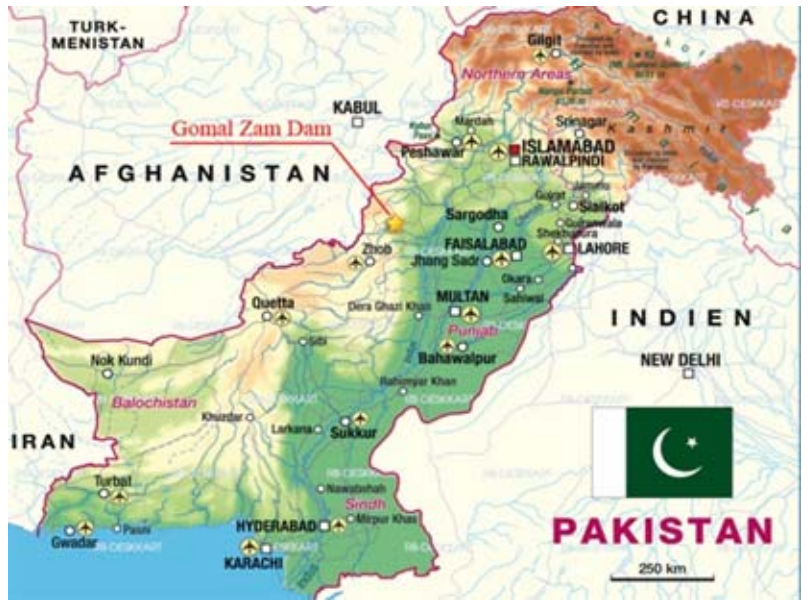

Fig. 1. The geographical location of the Gomal Zam Dam project site.

Power Development Authority (WAPDA) as the subcontractor to construct the dam. Work halted in October 2004 when two Chinese engineers were kidnapped and killed by Tehrik-i-Taliban Pakistan militants. When work resumed in 2007, Frontier Works Organization (FWO), a construction and military engineering branch of the Pakistani Army took over the project as the general contractor. A Chinese company, Sinohydro Corporation (referred as "the contractor" in this paper) was awarded the project as the subcontractor to complete the project.

The dam was designed by Tianjin Investigation, Design and Research Institute of Water Resources and Hydropower (TIDI) under the Ministry of Water Resources of China and constructed by the Chinese Sinohydro Corporation. The project was initially signed to Sinohydro Corporation in the form of engineering, procurement and construction (EPC)-turnkey contract at the cost of Rs. 5,303,285,000 (US\$87.225 million) in April 2007. The time for completion of the project was first agreed to be three years and 120 days. Due to financial constraints, 2010 flood disaster, and various other reasons discussed in this paper, the completion of dam and powerhouse was delayed until April 2011 and March 2013 respectively. The project was completed and officially inaugurated in September 2013.

\section{Brief Project Overview}

The Gomal Zam Dam project includes a division type hydropower station. Two power intakes embedded on the right abutment of the roller contacted concrete 
(RCC) gravity arch dam. The power house is located behind the dam on right abutment, installed of two 8.7 MW turbine units. A headrace tunnel was formed to connect power head between the two power intakes and the two turbine units. Figure 2 shows the early stage of the construction site.

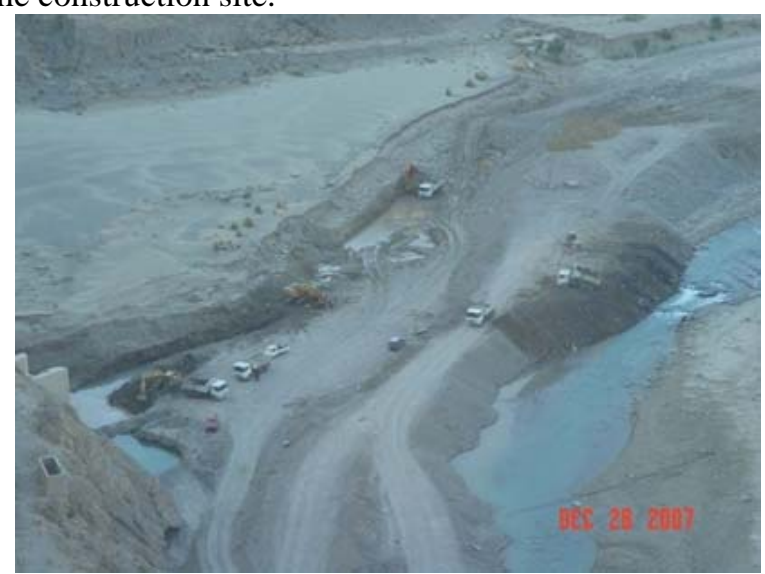

Fig. 2. The construction site in its early stage.
During the construction, due to the local financial constraints, supply market fluctuation, irrational managerial system, natural disaster, political instability, and culture differences, the construction management level had faced many challenges, which negatively impacted the construction schedule control, cost control, safety control and quality control. Table 1 presents the scope of the project. The final construction cost exceeds US\$100 million. Given the size and value of the project, any unexpected uncertainty and interruption might negatively impact the every level of the management in their project control, and furthermore result in tremendous financial loss. Figure 3 presents the project organization. Since the investment for such a key project is huge, it brought a lot of opportunities for international companies. In fact, several international companies from different countries were involved in Gomal Zam Dam project as subcontractor hired by Sinohydro.

Table 1. Scope of project for Gomal Zam Dam.

\begin{tabular}{|c|c|c|c|}
\hline No. & Subprojects & Major Subprojects & Quantity or Size \\
\hline \multirow[t]{9}{*}{1} & RCC Gravity Arch & Rock and earth excavation & $3100,000 \mathrm{~m}^{3}$ \\
\hline & Dam & Shotcrete and anchorage support & $42,200 \mathrm{~m}^{2}$ \\
\hline & & Dam body concrete (RCC \& CC) & $505,000 \mathrm{~m}^{3}$ \\
\hline & & Dam foundation curtain grouting & $25,000 \mathrm{~m}$ \\
\hline & & Dam abutments consolidation grouting & $52,000 \mathrm{~m}$ \\
\hline & & Elevation $680 \mathrm{~m}$ bottom outlet sluice & $3 \times 5 \mathrm{~m}$ \\
\hline & & Elevation 743.2m Stage I flood sluice & $5 \times 4 \mathrm{~m}(\mathrm{two})$ \\
\hline & & Elevation $750.4 \mathrm{~m}$ spillway sluice & $20 \times 13$ (four) \\
\hline & & Dam hydromechanics and electrical equipment installation & -0 \\
\hline \multirow[t]{4}{*}{2} & Adits in both & Tunnel excavation & $450 \mathrm{~m}$ \\
\hline & Abutments & Lining concrete for adits & $200 \mathrm{~m}$ \\
\hline & & Dam abutments curtain grouting & $80,000 \mathrm{~m}$ \\
\hline & & Shotcrete and anchorage support & $1,800 \mathrm{~m}^{3}$ \\
\hline \multirow[t]{5}{*}{3} & Water Intake and & Water intake sluice & $3 \times 4 \mathrm{~m}(\mathrm{two})$ \\
\hline & Headrace Tunnel & Headrace tunnel excavation & $500 \mathrm{~m}$ \\
\hline & & Headrace tunnel (include dam embedded portion) steel lining & $390 \mathrm{~m}$ \\
\hline & & Headrace tunnel concrete backfilling & $8,600 \mathrm{~m}^{3}$ \\
\hline & & Concrete grouting works & $2,400 \mathrm{~m}$ \\
\hline \multirow[t]{5}{*}{4} & Downstream & Rock and earth excavation & $110,000 \mathrm{~m}^{3}$ \\
\hline & Protection & Shotcrete and anchorage support & $1,250 \mathrm{~m}^{2}$ \\
\hline & Facilities & Plunge pool concrete lining & $3,600 \mathrm{~m}^{3}$ \\
\hline & & Tendon beam & $2,400 \mathrm{~m}^{3}$ \\
\hline & & Weir & $2,100 \mathrm{~m}^{3}$ \\
\hline \multirow[t]{5}{*}{5} & Powerhouse and & Rock and earth excavation & $10,800 \mathrm{~m}^{3}$ \\
\hline & Switchyard & Shotcrete and anchorage support & $9,800 \mathrm{~m}^{2}$ \\
\hline & & Powerhouse & $11,500 \mathrm{~m}^{3}$ \\
\hline & & Power generation equipment & 2 set \\
\hline & & Switchyard \& Miscellaneous & \\
\hline
\end{tabular}




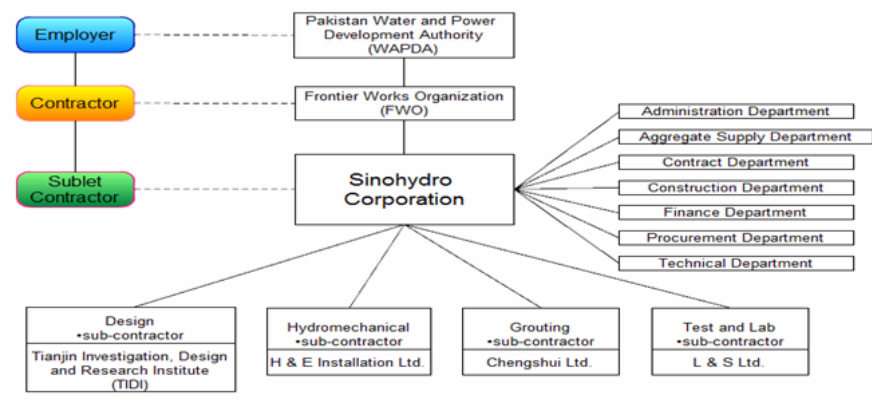

Fig. 3. Project organization chart.

\section{Risks Encountered During the Construction}

Although the contractor management level (Sinohydro) had been working actively with contractual parties after the resume of the work in 2007, it still faced many risks and difficulties due to the restraints of contract conditions, natural environment, unstable security issues and late payment from the employer which resulted in that the actual cost of the project exceeded the initial budget by over $16 \%$ and tremendous difficulties in fulfilling the contract. The risks encountered include:

\subsection{Harsh natural and inclement weather conditions and spacing}

The harsh natural environment, inclement and unpredictable weather conditions caused technical difficulties of the construction. For example, the pouring of RCC had to be conducted under extremely high temperature during the summer. The initial bid budget in temperature control of RCC was underestimated which caused increased cost and difficulties in implementing concrete quality control and project scheduling control. For example, cost increased due to additional technical measures including concrete curing and concrete additives. In addition, underestimated and unpredictable poor geological conditions such as rock fracture, fault on both abutments and dam foundation increased the cost of grouting treatment which exceeded the initial contract bid price. Figure 4 presents the view of the placement of roller compacted concrete.

\subsection{Numbering and risk associated with currency variations}

The Pakistani local currency (Rupee) continuously depreciated against the U.S. dollar during the construction. This resulted in total contract value shrank US\$8,160,000 due to Rupee's depreciation. Also, the procurement of permanent hydraulic equipment, construction equipment and construction materials from China caused US\$2,560,000 loss due to Chines Yuan's appreciation during the period of construction compared with the original total equipment cost of US\$20 million.

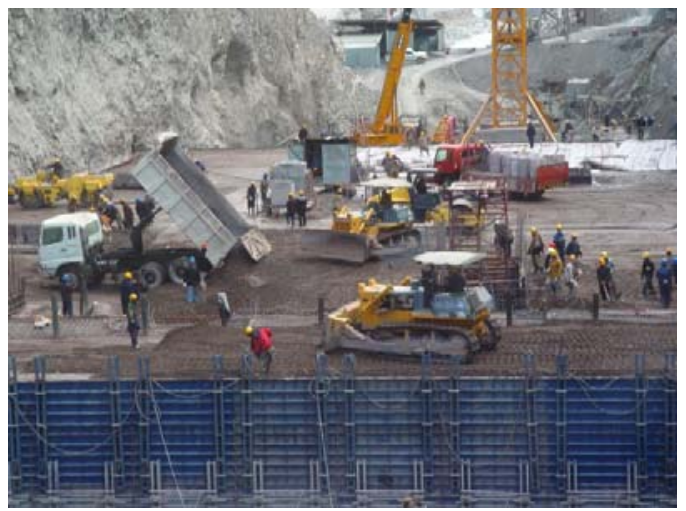

Fig. 4. Placement of roller compacted concrete.

\subsection{Inflation}

The total contract amount and unit prices of the line items were based on the projects resumed negotiations in early 2006 and the market prices at that time. However, approximately one year after the contract was signed, at the outset of the construction, both primary and auxiliary material prices had increased considerably. The price of primary construction material increased by 20 percent on average, while that of auxiliary materials increased by approximately 50 percent. Although the financial loss due to the price increase of primary construction materials was compensated through contract adjustments and changes, most of the auxiliary materials were not compensated. Figure 5 shows additional concrete lining preparation for the adit of the tunnel.

\subsection{Political uncertainty and military cracking down Taliban militants}

In the middle of construction, Pakistan army carried out military actions against Tehrik-i-Taliban in the South Waziristan tribal region where the dam project is located. The main access road to the project site passing the town of Tank was under military block and curfew irregularly. Military actions included checking 


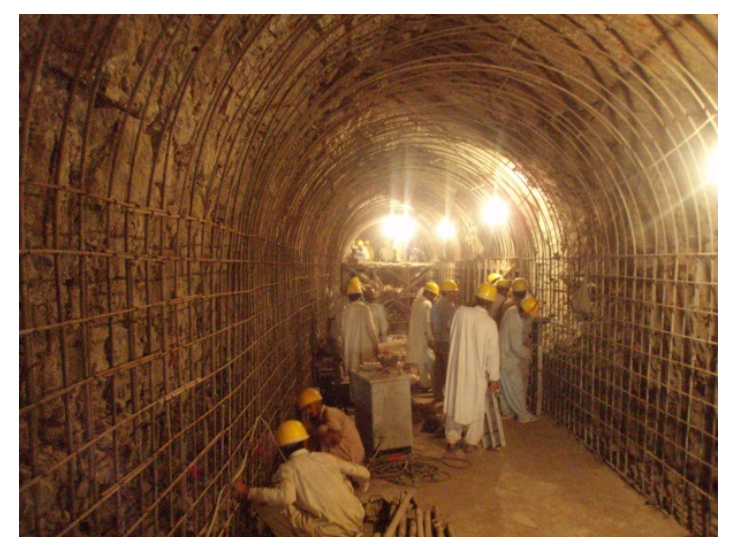

Fig. 5. Additional concrete lining preparation for the adit of the tunnel.

suspicious passing vehicles and personnel, shutting off local cellular and communication network systems irregularly. All these led to the loss of the Contractor's local skilled labor resources, serious interference of transporting gasoline, cement, fly ash, steel and other miscellaneous construction materials. Figure 6 shows the turbine pit in the powerhouse under construction.

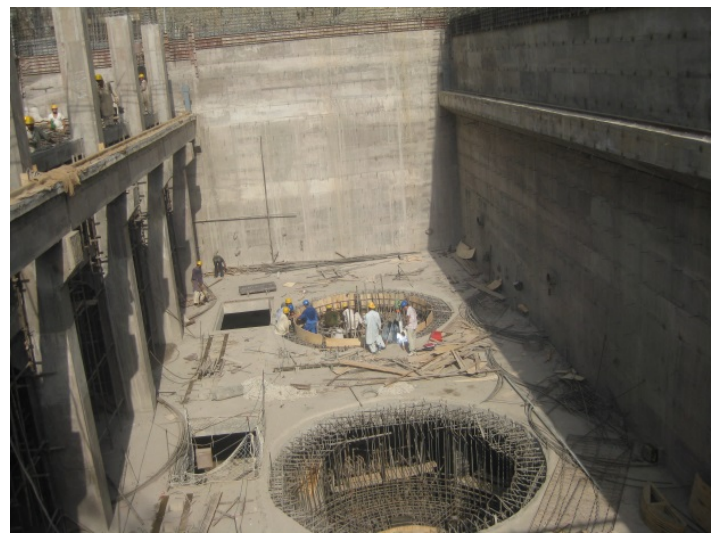

Fig. 6. Construction of the turbine pit in the powerhouse. Additional concrete lining preparation for the adit of the tunnel.

\subsection{Contract disputes}

During the construction, contractual disputes arose which led to delays of the construction and further the completion of the project. Several claims related to the extension of time (EOT) were filed. However, it normally took several months, even over one year, to receive final approvals. For one of the claims, for example, the compensation value was US\$20.32 million, EOT was 393 days. In general, it was difficult to get the claimed amounts approved and received by the
Contractor. The Contractor indicated to the employer that breach of contract might lead to termination of the contract. The contractor also halted the construction twice in an attempt to force the employer fulfill the contract.

\subsection{Financial issue}

Sections, sub-sections and sub-subsections are numbered in Arabic. Use double spacing before all section headings and single spacing after section headings. Flush left all paragraphs that follow after section heading The payment under this EPC-turnkey contract was divided into 52 interim payments corresponding to single or multiple milestones of the contract. The currency applied for the payment was agreed to be composed of 65 percent of US dollar and 35 percent of Pakistani Rupee. In the early stage of construction the interim payments were received on a timely manner. However, the continuously worsen financial condition of the Pakistan government caused the interim payment interrupted for several times. The overdue payment was once accumulated up to US\$11,150,000 which consists of US\$2.18 million retention money and US\$8.97 million of three interim payments. The overdue payment was once delayed exceeded 90 days. Figure 7 shows the concrete formwork for the power intake and precast concrete gallery.

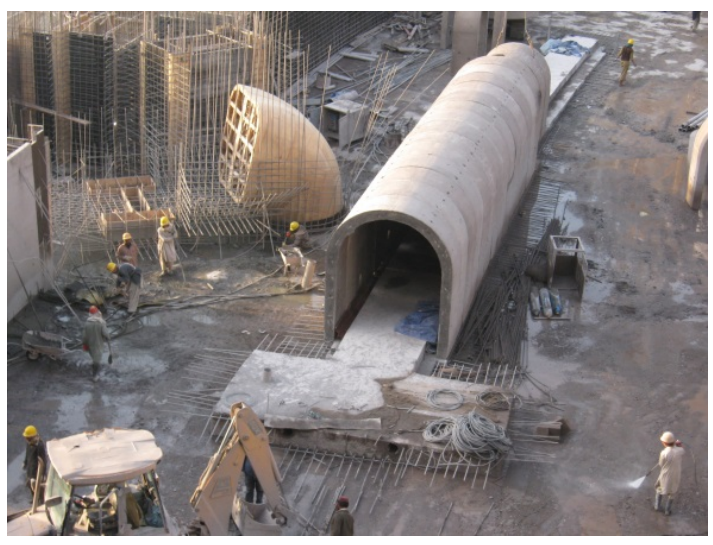

Fig. 7. Formwork for power intake and precast concrete gallery.

\section{Countermeasures}

Shortly after the negative circumstances occurred as above mentioned, the management level, the 
Administration Department of Sinohydro conducted thorough an analysis on the actual operation conditions, including financial, subcontractors and schedule on concrete pouring, mechanical and electrical installation. Based on the analysis, it was predicted that by September 2009, the predicted financial loss would be US $\$ 10,210,000$.

To mitigate the huge loss and the unfavorable situation, the contractor took a series of measures as follows:

- Optimized and fine-tuned some auxiliary designs to reduce the quantity of work, total work hours and equipment hours, and/or reduce the difficulty level of the construction;

- Optimized the construction plans and schedules by overlapping activities to compensate the time lost due to various situations occurred;

- Reallocated resources to reduce direct costs; and changed procurement plans ahead of prescheduled and increase lead time;

- Actively communicated with the owner, i.e., the WAPDA. Through communications and negotiations directly or through Sinohydro Corporation; contract disputes and compensation claims filed were solved between the WAPDA and Sinohydro;

- Actively tracked implementation of various measures; accelerated cash flow to reduce financial costs and interest of loans.

During the construction, the Contractor developed a series of internal cost-cutting measures. The Contractor took a proactive strategy on this special contract. Breakthroughs were made on contractual dispute resolutions. However, due to the poor domestic economic conditions, severe budget shortfalls of the owner's funds, and other uncontrollable foregoing objective factors causing delays, claims were keeping going and huge losses continued to increase throughout the project. Figure 8 shows the airscape view of the dam during construction.

\section{Discussion and Recommendations}

Construction risks are numerous and can be classified into construction and finance related, which include safety, cost, schedule, quality; factors that could affect those effects include social and political stability, government policies and managerial system, natural geographical environment, societal development level, and cultural differences. Defining risk and deciding

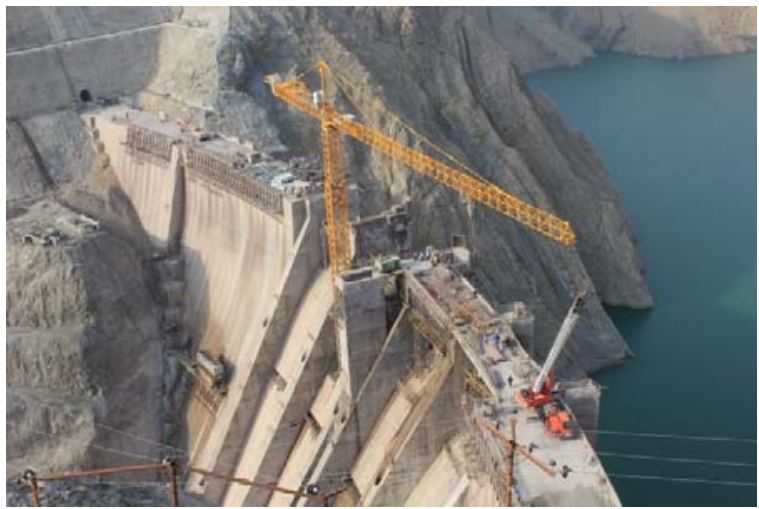

Fig. 8. Airscape view of the dam during construction.

how to mitigate the defined risk is a critical step in the international construction project. The Gomal Zam Dam Project is one of the special key infrastructure projects in Pakistan. Such project is quite different from infrastructure construction projects conducted in most other countries. For a large size of construction project in Pakistan, like the Gomal Zam Dam project the challenges faced by the construction managers are far more than that from a domestic construction project. The experience of Gomal Zam Dam project could help project managers outside Pakistan to understand this type of project and manage possible future business in Pakistan or similar countries. The experience lessons learned from Gomal Zam Dam project including the planning, risk mitigation, implementation mechanisms and specialized measures could be of reference values to global contractors pursue projects in Pakistan or similar countries or countries in surrounding area. Several factors should be considered in conducting this type of projects:

One of the features of the macro-environment for business in Pakistan, unlike industrialized countries, is that the Pakistan government and its politics have had a significant influence on construction in their country because of all of the unique issues the country has to deal with. It usually has unique government/owner environment. Consequently, business ethics has been an issue and detrimental to its economy and to the construction trade specifically. Not only does the corruption affect the economy, so does the unrest of the people that live there due to the conditions they live in and the unrest due to the violent groups such as the Taliban that reside in Pakistan. All of these issues do not only affect the people and the economy, they affect 
all businesses in the country including construction (DOD, 2009). The Sinohydro project team considered little, in the bidding stage, about the impact of the local politics and uncertainty on the project cost and schedule.

The combined factors of political uncertainty and low social development level (49.9 literacy rate and $74 \%$ of the population living in slum settlements (Nawaz and Ikram, 2013)) caused the difficulties to find skilled labors during the construction. The implication of cultural differences did not have as great of an impact on the project performance as previously believed. This may be due to the globalization of business today. Poor climate and geological conditions were also the major factors that impacted the project negatively.

A thorough risk analysis and evaluation should have been conducted in the bidding stage by the bidder. However, there were only a little information and specifications were available or received from the owner. The company did not assign a team to review the project contract, technical specification to identify the risks prior to accepting the contract. Figure 9 presents the upstream view of the dam.

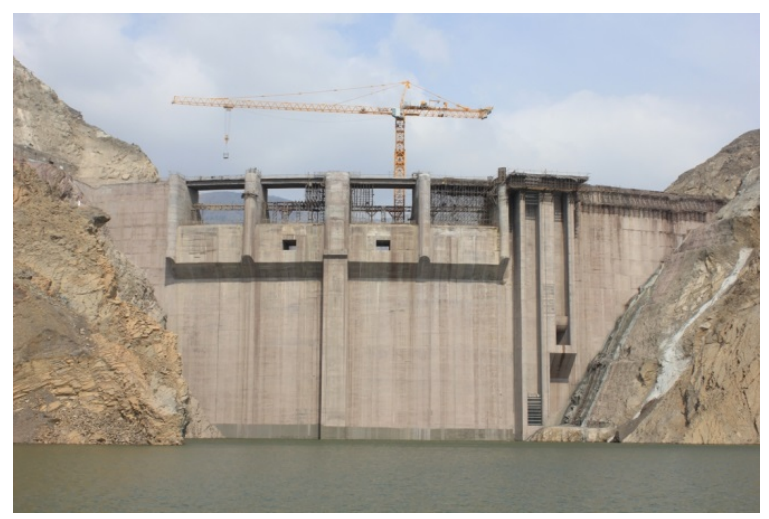

Fig. 9. Upstream view of the dam.

One of strategies to manage risk by the risk management team in a company is to exposure to contracting work in countries that will not execute a project by global standards and/or allied goals. The most common mode to managing this risk is through organizations that both share the same ideals and share common rules. The World Trade Organization (WTO) is one such example. As an organization that promotes the trade of goods and services among its members, the WTO helps its member countries follow stricter guidelines that allow for fewer claims. The FIDIC procedures are another way to manage risk in international construction project. These procedures are an outline for bidding, qualification, and contracting for owners, contractors, and others in construction. Using these standard practices reduces the risks associated with other contracting methods. Particularly, the prequalification process for potential bidders reduces the risk of owners and construction managers with their subcontractors. Unfortunately this is not the case of the Gomal Zam Dam Multi-Purpose project.

Once a contract is awarded, the risk management shifts somewhat from the overall company management to the project management team. The project management team is responsible for risk management for tangible, identifiable items such as the cost of the project. The construction manager is responsible for budgeting costs based on an estimate provided during the bid process. The construction manager must confirm that the estimate is reasonable and manageable. His first responsibility is to notify the project management if the estimate will never be enough to cover the cost of the project. If the project's estimate can be converted into a logical cost of accounts, the construction manager will be responsible for managing the risk of exceeding the project budget. The risk of exceeding budgets can be mitigated in several ways: assigning an individual to manage a sub-project with greater detail than the overall project budget, tracking daily costs with particular attention to details of cost/quantities only, etc.

Another way to mitigate the risk on an mega international construction project is through the continual management of the project schedule. Many projects have incentives for schedule completion, including financial motivation (this project does not have). Managing the time durations of project-specific tasks allows the project's management to more closely tracks the completion date - and potentially could result in large incentives for the subcontractor. However, if the schedule is not maintained based on the subcontracts, the subcontractors stands to lose money based on lack of performance. When a subcontractor is late in project delivery, it could be the project's owner that has enormous negative fallout from the extension. Product may be pre-sold, operations may not have a location to work from during startup, or the owner has financing payments due. Any number of issues of this sort needs to be identified, addressed, and eliminated as a part of the project's risk management. 


\section{Conclusions}

The construction was completed in August 2013 accepted by the inspection committee in terms of quality. Since it started to generate power this August, it has supply the daily consumption electricity for both Wana town and Tank town which accommodate approximately 25,000 families. This dam will also serve more than 10 million people with irrigation water. Global construction companies must identify the risks in an international project and employ appropriate methodologies and skills to win in the real-life game of international construction. In the bidding stage, the bidder must assign a risk analysis team to fully understand the construction process and scope of work. The key to risk management is clear communication and follow-up. Improved understanding the risks and support for project staff would improve the overall success of the project. A well-defined understanding of the risks and a clear, concise resolution to said risk is the key to success.

\section{References}

1. Construction Industry Institute (CII). Risk assessment for international projects (Research Report 181-11). Austin, TX: CII, 2003.

2. DOD, Defense Talk. Pakistan tops list of challenges, gates said. Accessed October 22, 2013 at http://www.defencetalk.com/pakistan-tops-list-ofchallenges-gates-21773/, 2009.

3. IHS. Global construction outlook: Executive overview. Accessed on October 15, 2013 at http://www.ihsglobalinsight.com, 2013.

4. T. Nawaz, and A. Ikram, Unethical practices in Pakistani construction industry. European Journal of Business and Management, 5(4), 188-204, 2013.

5. J. Raftery, B. Paadilla, Y. H. Chiang and B. Tang, Globalization and construction industry development: implications of recent developments in the construction sector in Asia. Construction Management \& Economics, 16(6), 729-737, 1998.

6. J. A. Walewski, G. E. Gibson and E. F. Vines, International project risk assessment for international construction projects. In the Proceedings of the 19th International Cost Engineering Congress (ICEC), Ljubljana, Slovenia, 2006. 